\title{
JoHANN WOLfGANG Von GOETHE
}

\section{Canto de los espíritus sobre las aguas}

El alma humana se parece al agua

que caída del cielo sube al cielo

y desciende de nuevo hacia la tierra

en alternancia eterna.

Del alto precipicio

baja el torrente claro

y después se disuelve en su belleza

en gotas de vapor

sobre la roca lisa.

Como velo ondulante

la toca apenas

y rumoroso sigue hacia el abismo.

Si los agudos riscos

se oponen al descenso

torna espuma su ira y poco a poco

continúa hasta la sima.

Ya en la tierra

por los prados del valle se desliza

hasta el sereno lago

en que miran su rostro las estrellas.

Para la ola el viento es tierno amante

que levanta las olas espumosas.

El alma humana se parece al agua.

Nuestro destino es semejante al viento. 